\title{
Surface and Ultrastructural Feeding Injury to Strawberry Leaves by the Twospotted Spider Mite
}

\author{
Richard J. Campbell, Randolph L. Grayson ${ }^{2}$, and \\ Richard P. Marini ${ }^{3}$ \\ Department of Horticulture, Virginia Polytechnic. Institute and State \\ University, Blacksburg,. VA 24061 \\ Additional index words. Fragaria $\times$ ananassa, Tetranychus urticae, electron optics
}

\begin{abstract}
Scanning and transmission electron microscopy were used to investigate damage to strawberry (Fragaria xananassa Duch.) leaves caused by twospotted spider mite (Tetranychus urticae Koch.). Mites damaged epidermal cells on the lower leaf surface, but did not damage major vascular elements of the leaf. Mite-damaged spongy and palisade parenchyma cells had coagulated protoplasts, with some cells devoid of cellular contents. Mesophyll cells adjacent to damaged regions showed no ultrastructural distortion or disruption of chloroplasts.
\end{abstract}

Tetranychid mites are important foliagefeeding pests on a wide range of horticultural crops. Mite feeding reduces chlorophyll and nitrogen content of leaves (Campbell and Marini, 1990) and adversely affects many physiological functions, including photosynthesis and transpiration (Hall and Ferree, 1975; Sances et al., 1981). Sances et al. (1982) measured a $10 \%$ reduction in photosynthesis ofwinter-grown strawberry plants following 2250 mite days per leaflet, but Hall and Ferree (1975) reported a $26 \%$ reduction in photosynthesis of greenhouse-grown apple trees following only 135 mite days per leaf. Thus, strawberry is more tolerant of mite feeding than apple. The mechanism of this tolerance in strawberry has not been characterized. McGregor mite (Tetranychus mcdanieli $\mathrm{McGregor})$ damaged apple leaf cells

Received for publication 17 Oct. 1989. The cost of publishing\&this paper was defrayed in part by the payment of page charges. Under postal regulations, this paper therefore must be hereby marked advertisement solely to indicate this fact. ${ }^{1}$ Graduate Student.

Associate Professor, Electron Microscopy Laboratory.

${ }^{3}$ Associate Professor. by direct stylet penetration and caused extensive ultrastructural disruption of adjacent unpenetrated cells (Tanigoshi and Davis, 1978). This ultrastructural damage (particularly to chloroplasts) in adjacent cells was thought to be an important factor in reduced gas exchange capacity of the apple leaf. Using light microscopy, Sances et al. (1979) were unable to detect any gross morphological distortion in strawberry mesophyll cells adjacent to mite-damaged cells. Ultrastructural integrity could not be adequately evaluated with the magnification used in the study. The absence of ultrastructural disruption in strawberry leaves could be one factor in its greater tolerance of mite feeding. The objective of this study was to investigate cellular injury caused by mite feeding on strawberry leaves and to determine whether ultrastructural disruption of adjacent cells occurs in this species.

Ten 'Tribute' strawberry plants were planted on 20 Nov. 1988 and grown under natural light conditions in a white-washed (50\% shade), fan- and pad-cooled glasshouse. The planting medium consisted of equal parts by volume of peat, perlite, and vermiculite. Fertilizer was applied weekly as a $200-\mathrm{mg} \mathrm{N} / \mathrm{liter}$ solution of a $20 \mathrm{~N}-8 \mathrm{P}-15 \mathrm{~K}$ soluble fertilizer (Peters Fertilizer Products, W.R. Grace and Co., Allentown, Pa.). On 16 Dec. 1988, five plants were chosen at random and infested with twospotted spider mite (TSM), and five plants were maintained as mite-free controls by manual mite removal. The-most recent fully expanded leaf on each plant was chosen as a test leaf at this time. Mites were allowed to develop naturally, and mobile stages of mites were counted on each test leaf (three leaflets) every week (same leaf every week). Mite population density was expressed as mite days (MD) by averaging the number of mites counted each week and multiplying by the number of 24-hr periods elapsed between counts. Mites were removed from control plants each week.

All tissue samples were collected at 11:00 AM on 24 Jan. 1989. Test leaves were removed and immediately immersed in cold primary fixative of $4 \%$ paraformaldehyde : gluteraldehyde $(\mathrm{v} / \mathrm{v})$ and $0.1 \mathrm{M}$ sodium cacodylate $(\mathrm{pH} 7)$ for $12 \mathrm{hr}$. Tissue samples for scanning (SEM) and transmission electron microscopy (TEM) consisted of 4- and 1$\mathrm{mm}^{2}$ tissue pieces, respectively. One SEM and one TEM sample were removed from each leaflet to provide 15 control and 15 miteinfested samples for both SEM and TEM. Samples were washed in $0.1 \mathrm{M}$ phosphate buffer ( $\mathrm{pH} 7$ ) and post-fixed in $2 \%$ osmium tetroxide $(\mathrm{pH} \mathrm{7)}$. Samples were then taken through an alcohol dehydration series $(15 \%$, $25 \%, 40 \%, 50 \%, 70 \%$, and $95 \% \mathrm{ETOH})$. SEM samples were critical-point dried, sputter-coated to $20 \mathrm{~nm}$ with gold/paladium, and mounted on aluminum stubs for observation under a Phillips (Mahwah, N.J.) 505 SEM $(15 \mathrm{kV})$. TEM samples were taken through an acetone embedding series, embedded in Spurr's resin, sectioned with a glass knife, and observed with a Zeiss (Thornwood, N.Y.) $10 \mathrm{C}$ TEM $(80 \mathrm{kV})$.

When samples were collected, each leaflet had accumulated about $700 \mathrm{MD}$ (20 MD/ $\left.\mathrm{cm}^{*}\right)$. There was no apparent visible damage when samples were collected. No visible damage (bronzing) was observed on apple leaves following $540 \mathrm{MD}$ of TSM, although photosynthesis was reduced (Hall and Ferree, 1975). Avery and Briggs (1968) demonstrated that speckling or bronzing resulted from European red mite (ERM) damage to 

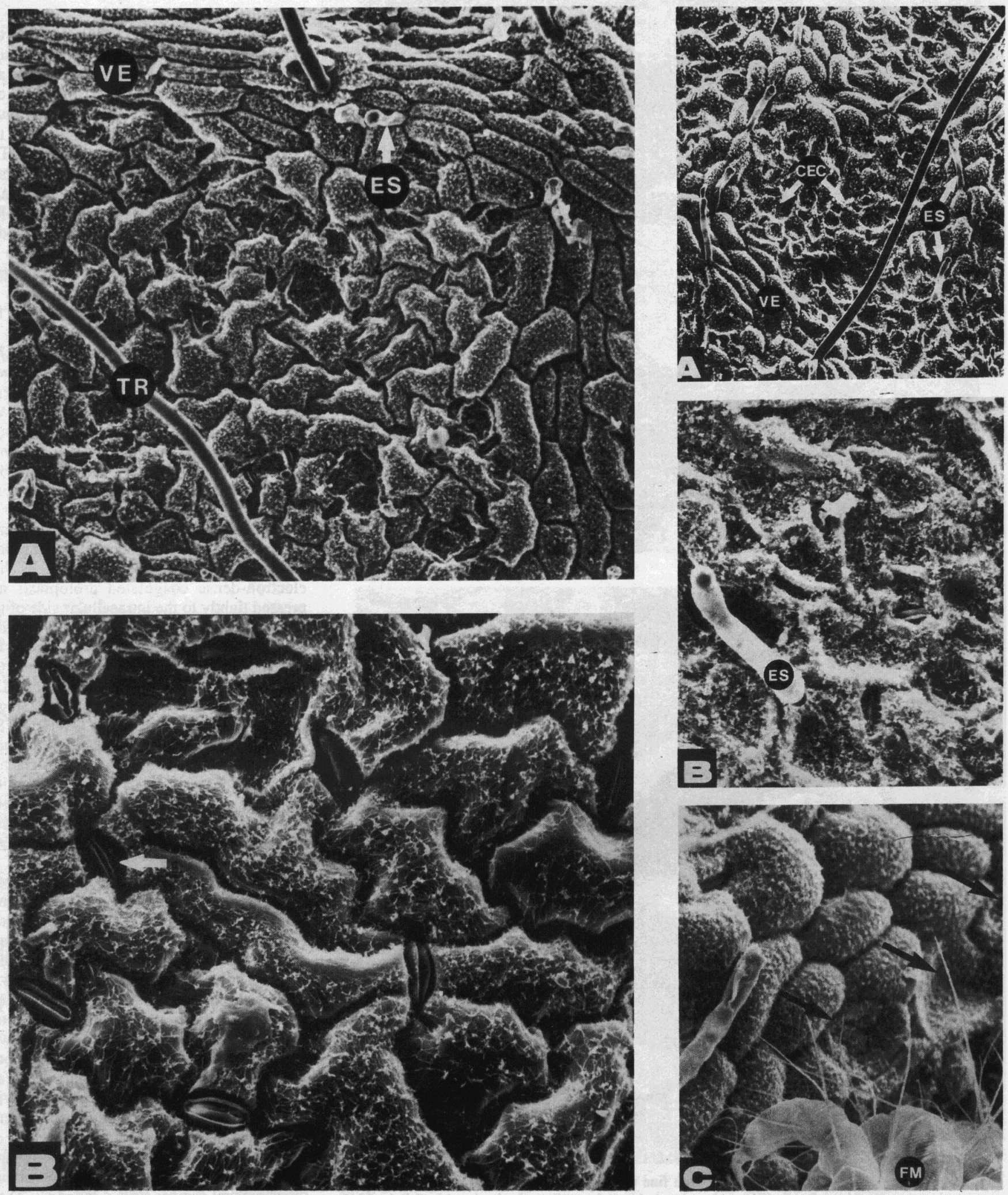

Fig. 2. The lower (abaxial) epidermis of a mitedamaged 'Tribute' strawberry leaf. (A) Areas of collapsed epidermal cells (CEC) and undamaged vascular elements (VE) with egg stalks (ES) attached $(\times 194)$. (B) Higher magnification of irregular, collapsed epidermal cells $(\times 563)$. (C) Collapsed epidermal cells near feeding mite $(\mathrm{FM})(\times 703)$.

the uppermost palisade layer and occurred face. TSM feed predominantly on the lower leaf surface, causing little damage to the uppermost palisade layers and minimal bronzing; therefore, significant leaf damage may occur without detectable visible damage.
Fewer than 30 MD per control leaflet had accumulated at sampling.

The lower epidermis of control plants had an ordered arrangement of epidermal cells, with little visible disruption (Fig. 1). Minor epidermal disruption found on the control samples was probably due to limited mite feeding before removal, as evidenced by the presence of a few egg stalks. Lower epidermal cells were injured by mites on the in- 

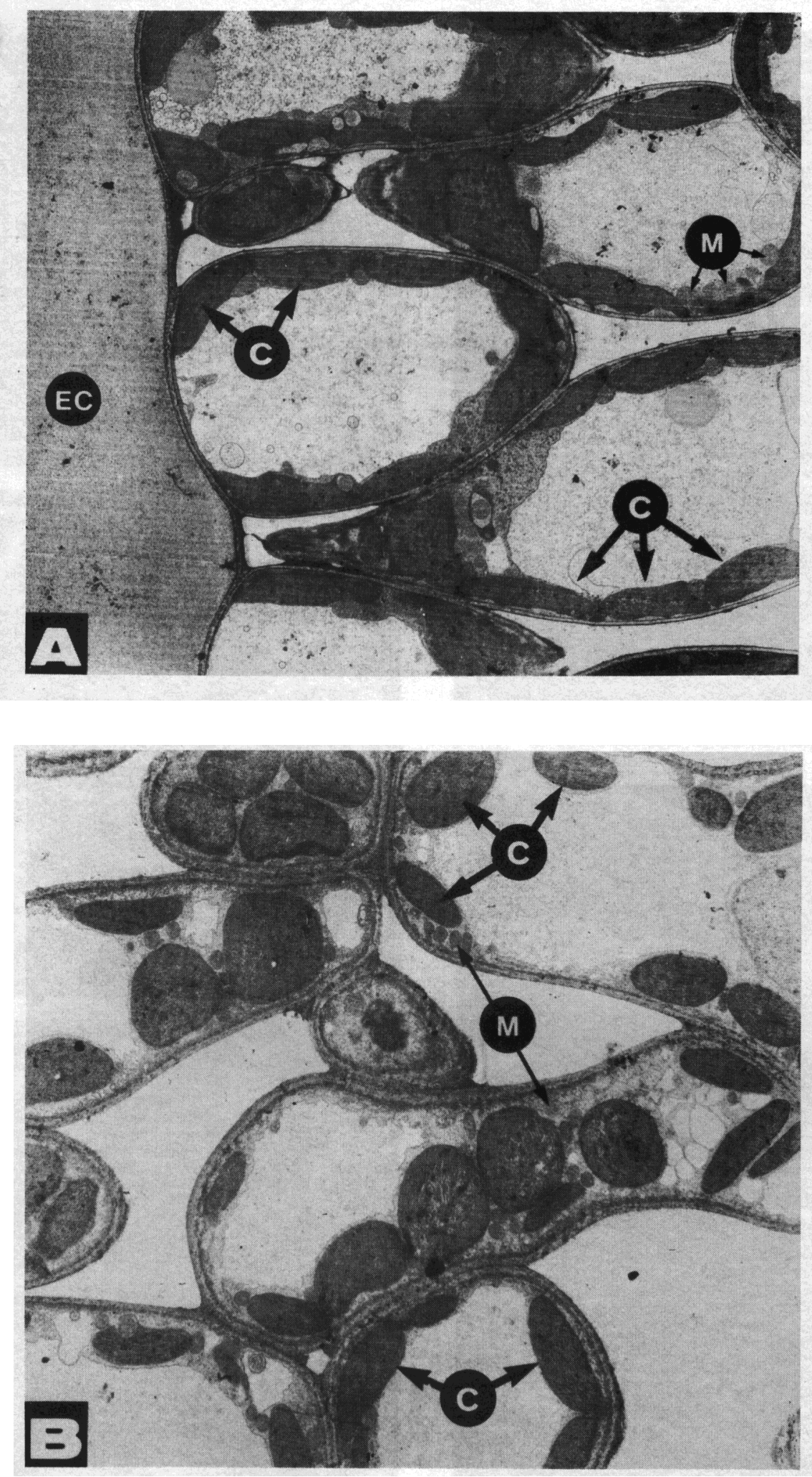

fested leaves (Fig. 2 A and B). Damaged epidermal cells appeared sunken in all of the mite-infested samples observed. Cells in vascular elements showed no visible mite injury and were used extensively for anchoring egg stalks (Fig. 2 A and B). As previously reported in strawberry (Sances et al., 1979), mite-infested samples had fewer open sto- epidermal cells (Fig. 2C).

Tanigoshi and Davis (1978) observed the penetration of McGregor mite stylets through the periclinal walls of epidermal cells on apple. Avery and Briggs (1968) found no epidermal damage with ERM on apple or plum and surmised that stylets passed between the epidermal cells along the anticlinal walls. The light-microscopy techniques used in their study may not have been sufficiently sensitive to show mite-damaged epidermal cells. Using tissue preparation similar to our study, Sances et al. (1979) found no evidence of specific tissue injury to the lower epidermis of strawberry leaves with higher levels of TSM feeding. We have no explanation for the discrepancy with our results.

Thin-sectioned control samples (TEM) consisted of a typical strawberry leaf morphology with a single layer of bulbous epidermal cells, two to three layers of palisade parenchyma cells, loosely packed spongy parenchyma, and a single layer of flattened lower epidermal cells. Control samples showed ultrastructural integrity and order (Fig. 3).

Mite-damaged samples had fine ultrastructural disruption in the lower epidermal and mesophyll tissues. Injured cells had electron-dense coagulated protoplasts appressed tightly to the intracellular side of the cell wall (Fig. 4 A-D). These cells were devoid of discernable organelles, except for apparent chloroplasts contained within the coagulated protoplast (Fig. 4 A, B, and D). Similar damage was caused by McGregor mite in apple (Tanigoshi and Davis, 1978). The absorbance characteristics of these chloroplasts were not examined, but the presence of chloroplasts in otherwise empty mitedamaged cells may explain the poor relationships between chlorophyll content and mite feeding (Campbell and Marini, 1990; Sances et al., 1979).

In contrast to studies with apple, there were few completely empty cells and no electrondense material filling intercellular spaces (Tanigoshi and Davis, 1978). Injury to epidermal cells was confirmed by the presence of stylet holes through the periclinal walls of epidermal cells and continuing into the spongy parenchyma (Fig. 4C); Most damage occurred in the spongy parenchyma and lower palisade parenchyma, with the greatest percentage of injured cells adjacent to the vascular elements (Fig. 4B). In agreement with SEM observations, vascular elements themselves had no apparent damage.

Mesophyll cells adjacent to mite-damaged areas showed no apparent disruption or fine ultrastructural damage (Fig. $4 \mathrm{~B}$ and D). There was no distortion or swelling of the chloroplast granal or stromal thylakoids, or cupshaped chloroplasts, as described by Tanigoshi and Davis (1978) for mite-damaged apple leaves. Apple mesophyll cells adjacent to mite-damaged areas exhibited organelle degradation resembling the physiochemical responses to many plant stresses, including viral and fungal infections, cold injury, and chemical treatment. Proteolytic enzymes in the TSM saliva (Storms, 1971) may have 

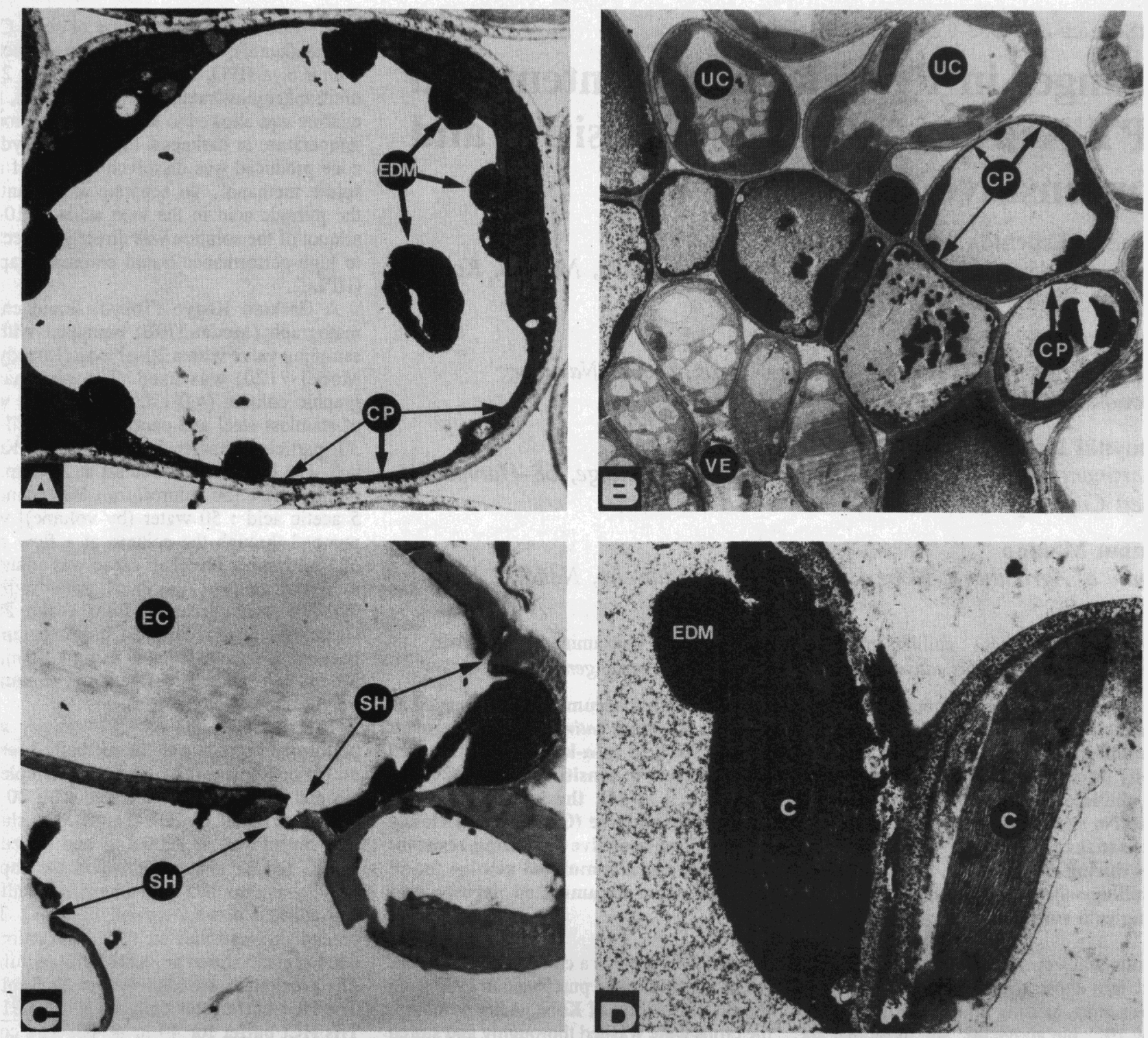

been a major cause of organelle destruction and protoplast coagulation. However, in our study (strawberry), the physiochemical disruption was confined to the directly penetrated cells, suggesting a differential hostplant response to the physiochemical stress.

This study indicates that mite feeding on strawberry leaves directly damages epidermal and spongy and palisade parenchyma cells. Contrary to findings with apple (Tanigoshi and Davis, 1978), however, there was no chloroplastic distortion in strawberry mesophyll cells-adjacent to mite-damaged tissues; Tanigoshi and Browne (1981) suggested that the expression of mite population densities may need modification to, compensate for gradual chloroplastic distortion and subsequent loss of photosynthetic function. Our results indicate that, for strawberry, the distortion of adjacent chloroplasts may not be an important factor. These results may also help explain the relative greater tolerance of strawberry than apple leaves to mite feeding.

\section{Literature Cited}

Avery, D.J. and J.B. Briggs. 1968. Damage to leaves caused by fruit tree red spider mite. Punonychus ulmi (Koch). J. Hort. Sci. 43:463-473.

Campbell, R.J. and R.P. Marini. 1990. Nitrogen fertilization influences the physiology of apple leaves subjected to European red mite feeding. J. Amer. Soc. Hort. Sci. 115:89-93.

Hall, F.R. and D.C. Ferree. 1975. Influence of twospotted spider mite populations on photosynthesis of apple leaves. J. Econ. Entomol. 68:517-520.

Sances, F.V., N.C. Toscano, E.R. Oatman, L.F Lapre, M.W. Johnson, and V. Voth. 1982. Reductions in plant processes by Tetranychus urticae (Atari: Tetranychidae) feeding on strawberry. Env. Entomol. 11:733-737.

Sances, F.V., J.A. Wyman, and I.P. Ting. 1979. Morphological responses of strawberry leaves to infestations of two-spotted spider mite. J. Econ. Entomol. 72:710-713.

Sances, F.V., J.A. Wyman, I.P. Ting, R.A. Van Steenwyk, and E.R. Oatman. 1981. Spider mite interactions with photosynthesis, transpiration and productivity of strawberry. Env. Entomol. 10:442-448.

Storms, J.J.H. 1971. Some physiological effects of spider mite infestation on bean plants. Neth. J. Plant Pathol. 77:154-167.

Tanigoshi, L.K. and R,W. Browne. 1981. Coupling the cytological aspects of spider mite feeding to economic injury levels on apple. Protection Ecol. 3:29-40.

Tanigoshi, L.K. and R.W. Davis. 1978. An ultrastructural study of Tetranychus mcdanieli feeding injury to the leaves of 'Red Delicious' apple (Acari: Tetranychidae). Intl. J. Acarol. 4:47-56. 